\title{
Enhancing Students' Learning Independence and Learning Achievement in Mathematics through Problem Posing Learning: An Action Research Study
}

\author{
Heni Lilia Dewi \\ Yogyakarta State University, Indonesia
}

\begin{abstract}
Learning achievement is not a major determinant in the success of learning, but also the need for attention on other aspects that can be used as a description of the quality of learning achieved by students, including affective ability. Students need to have a special behavior in learning called learning independence. Students with high learning independence: (a) tend to learn better in their own control than in program oversight, (b) be able to monitor, evaluate and organize their learning effectively; (c) save time in completing the task; and (d) organize learning and time efficiently. One of the learning design that is expected to improve student learning independence is Posing Problem learning. Problem posing is categorized into three, namely Free Problem Posing, Semi-Structured Posing Problem, and Structured Problem Posing. This study aims to improve and describe the increase independence and student achievement. The subjects of this study are vocational high school students of equal age with a high school in Indonesia. In addition, students have also given the material first before getting the problem-posing scenario. The measures and instrumentation in this study include the mathematical achievement test and learning independence scale. The analysis of the data indicated resources to the problem-posing learning that can improve student learning independence. Another finding is that the problem posed by a student may vary or even a new problem. This indicates that the success of students in posing the problem will certainly have implications for improving learning achievement that is in solving every problem.
\end{abstract}

Keywords: learning independence, learning achievement, problem posing.

\section{Introduction}

Education is fundamental in shaping the character of students to become a superior person in terms of cognitive, affective and psychomotor. In relation to quality learning, it should be noted how focusing a learning design. Focusing is not separated from the measurement of student achievement in school. However, in addition to learning achievement factors, attention should be paid to other aspects that can be used as a description of the quality of learning achieved by students. One that can be a benchmark in learning in the 2013 curriculum in Indonesia is affective ability. Students need to have a special behavior in learning called learning independence.

This is in line with the results of preliminary observations, that the average learning independence of the tenth graders in one of the vocational high schools in Indonesia is still in the medium category. In addition, preliminary diagnostic results indicate that there are still $15.63 \%$ of students still have low learning independence. In addition, in the learning process is still dominated by teachers. This is evident from the absence of a dominant activity undertaken by students, such students are not accustomed to not even dare to pose a problem. This means that students are still dependent on the instruction of the teacher.

There are several terms that have similarities with the meaning of learning independence of which is selfregulated learning, self-regulated thinking, and self-directed learning. There is a report that students who have high learning independence: (a) tend to learn better in their own supervision than in program oversight; (b) able 
to monitor, evaluate, and organize its learning effectively; (c) save time in completing the task; and (d) organize learning and time efficiently [1].

One instructional design that is expected to increase the independence of student learning is learning Problem Posing. Problem posing is the posing of problems by learners either with the "What If Not (WIN)" strategy. The issue can be a re-formulation or the establishment of a new problem or question based on the situation to be resolved. Problem posing is identified as an important activity in mathematics education [2]. This is supported by the claim that the posing problem is one of the key components of mathematical exploration [3]. This makes it possible to increase the independence of learning, because the familiar pose a problem, on an ongoing basis the students will get used to accepting challenges to learn without prompting by the teacher beforehand.

\section{Literature Review}

\subsection{Learning Independence}

Self-study is a situation in which learners are really responsible for all decisions related to learning and implementation decisions [4]. Meanwhile, the term independence of learning is also closely related to the learning process is done independently or independent learning. Independent learning is an active learning activity driven by the intention or motive to master a competency to overcome a problem, and built with the provision of knowledge or competencies that have been owned. In the learning process, the student should not rely on the teacher's help, supervision, and direction, but is based on self-confidence and self-motivation to achieve the learning objectives [5]. With the independence of learning, the learning process will be more meaningful for the students themselves. Based on this understanding, it can be said that the independence of learning is an encouragement that comes from within themselves to perform an action, where the act becomes his own responsibility.

Student learning independence can be seen through several indicators according to [6] namely: (1) metacognitive; (2) motivational; and (3) behavioural. While Schunk and Zimmerman suggested three main phases in the cycle of learning independence, namely: (1) designing learning; monitor learning progress during applying the design; and (3) evaluate the complete learning outcomes [1]. Based on some of these opinions, the indicators of learning independence used in this study include: 1) initiative and intrinsic learning motivation; 2) the habit of diagnosing learning needs; 3) set learning goals/targets; 4) monitor, organize, and control learning; 5) view difficulties as a challenge; 6) utilizing and locating relevant sources; 7) selecting, implementing learning strategies; 8) evaluate the learning process and outcomes; and 9) self-efficacy.

\subsection{Learning Achievement}

Mathematics achievement related to the success of learning as a result of mastering learning materials. Understanding mathematics achievement as the mastery of knowledge and skills developed in mathematics acquired through business process subject students in active interaction with the environment that can be seen from the results of students' mathematics learning [7]. While the achievement of learning happens when there is a change in a person's ability level that includes progress in science, changing attitudes and skills of what has been learned at school [8]. This means that learning achievement is not only determined by science but also refers to changes in skills and attitudes better.

There are several factors that influence learning achievement. It is revealed that learning achievement is influenced by internal factors and external factors [9]. More clearly, internal factors (within) consisting of intelligence, talent, learning strategy, motivation, attitude, interest, self-esteem, physical and mental condition, while external factors consist of family circumstances, social support, learning infrastructures, learning environments, opportunities, and teachers and teaching methods [10]. 


\subsection{Problem Posing}

Silver states "[p]roblem posing is defined as occurring when students are engaged in reformulating given problems and also when producing new problems or questions" [11]. This means that the problem posing is defined as an event when students are involved in reformulating a problem and generate a new problem or question. Furthermore, the notion of problem posing is not limited to the formation of a completely new problem, but can reformulate the problems ever given. The process of re-construction these problems can be done through various ways according to the stage of development of learners [12]. To that end, in general, teachers usually provide problems to be solved by the students. But outside the classroom, learners often identify and define their problems in their own way [13].

According to the above definition, problem posing consists of two important aspects, namely accepting and challenging. Accepting is related to the ability of learners to understand the situation given by the teacher or difficult situation encountered while challenging relates to how big the students are challenged with the given situation so that it raises the motivation to pose the problem [14]. While problem posing is also categorized into three, namely Free Problem Posing, Semi-Structured Problem Posing, and Structured Problem Posing [15].

Based on some of the above opinions, the authors conclude that the problem posing is posing problems by learners either reformulating or the formation of new problems or questions based on the situation at hand. Problem posing syntax used in this study refers to [16] which was then developed as follows.

TABLE I: Problem Posing Syntax

\begin{tabular}{|l|l|}
\hline \multicolumn{1}{|c|}{ Problem posing syntax } & \multicolumn{1}{c|}{ Learning activities } \\
\hline Step 1. Material review & $\begin{array}{l}\text { Giving prerequisite materials to students, then } \\
\text { presentation and explanation of the material to be } \\
\text { delivered. }\end{array}$ \\
\hline Step 2. Posing problems & $\begin{array}{l}\text { Students pose problems that may arise after } \\
\text { reviewing new materials or issues relating to the } \\
\text { material presented. }\end{array}$ \\
\hline Step 3. Solving problems & $\begin{array}{l}\text { Students try to solve the problems that have been } \\
\text { proposed. }\end{array}$ \\
\hline Step 4. Present the problem found and the solution & $\begin{array}{l}\text { Students do presentations finding and solving } \\
\text { problems to classmates so getting feedback and } \\
\text { improvement. }\end{array}$ \\
\hline Step 5. Evaluation & $\begin{array}{l}\text { Students conclude the material and recheck the } \\
\text { results of their work for a reflection of learning. }\end{array}$ \\
\hline
\end{tabular}

\section{Methods}

This research was conducted in Vocational High School (SMK) with age range 15-17 years. The study was undertaken in one class in one vocational school as many as 30 students. The type of research conducted is classroom action research that is divided into cycles. Each cycle includes (1) planning, (2) implementation and observation, and (3) reflection [17]. This methodology was selected because it provided the students with the opportunity to deeply understand the students' experiences through talking, listening, and observing them see their learning independence. The research design can be described as follows:

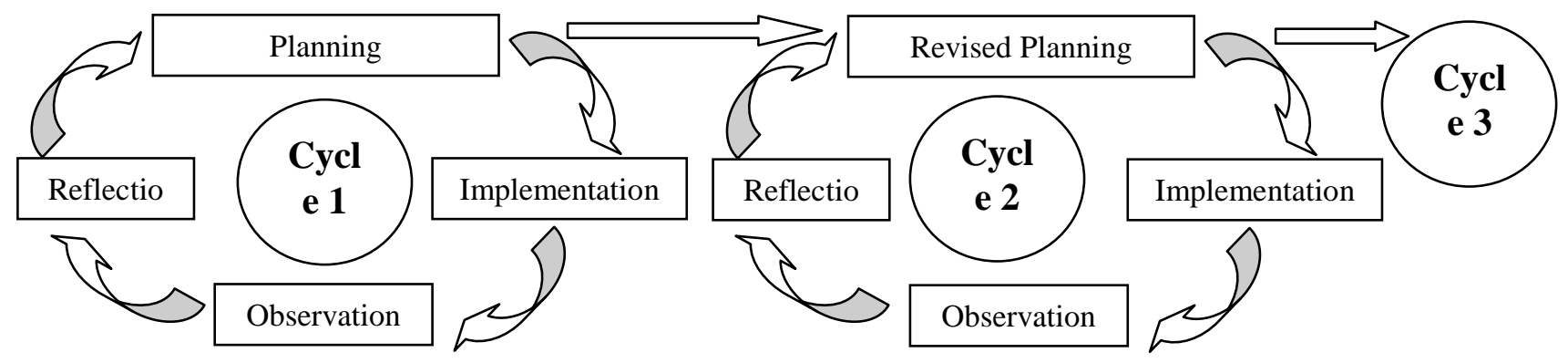

Fig. 1: The implementation process in a Class Action Research 
The measurement is done with achievement test and learning independence scale. The achievement test used multiple choice and the learning independence scale used the Likert scale. The data were analyzed using descriptive analysis to see how much improvement and how to improve students' learning independence and students' achievement. To facilitate implementation, it is determined the details of the target as a criterion for the success of actions described in the following table.

TABLE II: The Target of Action Research Success

\begin{tabular}{|c|c|c|c|c|}
\hline Variable & Interval & Criteria & Initial Condition & Target \\
\hline \multirow{6}{*}{ Learning Independence } & $147<X \leq 175$ & Veri High & $0,00 \%$ & $9.38 \%$ \\
\hline & $119<X \leq 147$ & High & $53.13 \%$ & $68.75 \%$ \\
\hline & $91<X \leq 119$ & Medium & $31.25 \%$ & $21.88 \%$ \\
\hline & $63<X \leq 91$ & Low & $15.63 \%$ & $0 \%$ \\
\hline & $35<\mathrm{X} \leq 63$ & Very Low & $0 \%$ & $0 \%$ \\
\hline & Average & Medium & 115.25 (Medium) & High \\
\hline \multirow{2}{*}{ Learning Achievement } & pass $\geq 75$ & & $3.13 \%$ & $78.13 \%$ \\
\hline & Average & 75 & 44.375 & 80 \\
\hline $\begin{array}{l}\text { Implementation of } \\
\text { problem posing learning }\end{array}$ & $\begin{array}{l}\text { Learning } \\
\text { implemented } \geq 90 \%\end{array}$ & & $0 \%$ & $90 \%$ \\
\hline
\end{tabular}

\section{Result and Discussion}

Here are the results of research conducted for 2 cycles.

TABLE III: Data on Classroom Action Research Activities

\begin{tabular}{|c|c|c|c|c|c|c|}
\hline \multicolumn{7}{|c|}{ Determination of Indicators of Achievement of Improving the Quality of Learning in Classroom Action Research } \\
\hline Variable & Interval & Criteria & $\begin{array}{c}\text { Initial Condition } \\
(\%)\end{array}$ & Target $(\%)$ & Cycle 1 & Cycle 2 \\
\hline \multirow{6}{*}{ Learning Independence } & $120<X \leq 150$ & Very High & $0 \%$ & $9.38 \%$ & $3.13 \%$ & $12.50 \%$ \\
\hline & $100<\mathrm{X} \leq 120$ & High & $53.13 \%$ & $68.75 \%$ & $65.63 \%$ & $65.63 \%$ \\
\hline & $80<\mathrm{X} \leq 100$ & Medium & $31.25 \%$ & $21.88 \%$ & $28.13 \%$ & $21.88 \%$ \\
\hline & $60<X \leq 80$ & Low & $15.63 \%$ & $0 \%$ & $3.13 \%$ & $0 \%$ \\
\hline & $30<\mathrm{X} \leq 60$ & Very Low & $0 \%$ & $0 \%$ & $0 \%$ & $0 \%$ \\
\hline & Average & & 115.25 (Medium) & High & 118 (Medium) & 121.8125 (High) \\
\hline \multirow[t]{2}{*}{ Learning Achievement } & pass $\geq 75$ & & $3.13 \%$ & $78.13 \%$ & $53.13 \%$ & $81.25 \%$ \\
\hline & Average & & 44.375 & 80 & 70.625 & 78.125 \\
\hline $\begin{array}{lr}\text { Implementation } & \text { of } \\
\text { problem } & \text { posing } \\
\text { learning } & \\
\end{array}$ & $\begin{array}{l}\text { Learning } \\
\text { implemented } \geq \\
90 \%\end{array}$ & & $0 \%$ & $90 \%$ & $85.47 \%$ & $94.23 \%$ \\
\hline
\end{tabular}

Based on the results of research, obtained the implementation of action research in the form of Problem Posing learning managed to improve student learning independence. It is based on the success criteria of the action as follows.

1. Implementation in accordance with the learning of mathematics by using Problem Posing. Where the average percentage of observations reached $\geq 90 \%$, ie equal to $94.23 \%$. This can happen because of the reflection of the first cycle which became the material of evaluation and improvement so that in the second cycle, problem posing learning can be done optimally.

2. The average percentage of student learning independence as a whole is in high criteria with $12.5 \%$ of students have very high learning independence category, $65.63 \%$ of students have high learning independence category, and $21.88 \%$ of students have moderate learning independence category. This happens because through learning problem posing, that is student asking problem, hence student can 
independently arrange even solve the problem. So that students automatically get used to independently, both in preparing and solving problems without being told by others (teachers). This has an impact on improving student learning independence. The results of this study are in line with the findings that said that the independence of learning can be improved through learning problem posing. This means learning problem posing can improve students' learning independence [18] [19].

3. The average percentage of students who achieved the minimum criteria of learning achievement (KKM) as a whole reached $81.25 \%$. This research is focused on the affective aspect of learning independence. However, in the implementation, researchers also see the cognitive aspects of learning achievement. Based on the results of research, student achievement can also be improved through learning problem posing. Nevertheless, the achievement of the average achievement or the learning outcomes of students is still below the target, which is 78.125 under 80 . But overall, the implementation of class action in the form of learning posing problems has been successful in increasing the independence of student learning, even learning achievement. This research is in line with the opinion which says that problem posing method of instruction has significantly increased students' mathematical academic achievement [20].

\section{Conclusion}

Based on the results of research and discussion, it can be concluded that the problem-posing learning can improve learning independence. With the stages of reviewing the material, posing problems, problem-solving, and the presentation of results can improve students' learning independence. This is indicated by the achievement of the target of student learning independence which has increased from before the action until after getting the action.

There is an increase in learning independence, that is, at the end of the second cycle, $12.5 \%$ of students have very high learning independence category, $65.63 \%$ of students have high learning independence category, and $21.88 \%$ of students have moderate learning independence category with average independence learning classes on high categories. In addition to affective aspects, learning achievement is also proportional to the increase in learning independence.

\section{Acknowledgements}

This research was funded by Indonesia Endowment for Education (LPDP).

\section{References}

[1] Sumarmo, U., "Kemandirian Belajar: Apa, Mengapa Dan Bagaimana Dikembangkan pada Peserta Didik", presented at Mathematics Education Seminar in Yogyakarta State University, Indonesia, 2006.

[2] Kojima, K., \& Miwa, K. (2008). A system that facilitates diverse thinking in problem posing. International Journal of Artificial Intelligence in Education, Vol 18 Issue 3, pp. 209-236. Available:http://dl.acm.org/citation.cfm?id=1454281

[3] Cai, J., \& Hwang, S. (2002). Generalized and generative thinking in US and Chinese students' mathematical problem solving and problem posing. The Journal of Mathematical Behavior, Vol 21 Issue 4, pp. 401-421. Available: http://doi.org/10.1016/S0732-3123(02)00142-6

[4] Nagpal, MS. Kavita, dkk. (2013). Independent Learning and Student Development. International Journal of Social Science \& Interdisciplinar Research, Vol 2 Issue 2, p. 28.

[5] Mudjiman, H. (2009). Belajar Mandiri (Self-motivated Learning). Surakarta: UNS Press.

[6] Zimmerman, B. J. (1989). Self-Regulated Academic Learning. Journal of Educational Psychology, No. 81, pp. 329-339. https://doi.org/10.1037/0022-0663.81.3.329

[7] Sirait, Erlando Doni. (2016). Pengaruh Minat Belajar terhadap Prestasi Belajar Matematika. Jurnal Formatif, Vol 6 Issue 1, pp. 35-43. 
https://doi.org/10.30998/formatif.v6i1.750

[8] Bloom, B. S. (2007). Taxonomy of Educational Objective Cognitive Domain. Ney York: David Mc. Kay.

[9] Slavin, R. E. (2011). Educational psychology. Boston: Allyn \& Bacon.

[10] Purwanto, M. N. (2010). Psikologi Pendidikan. Bandung: Remaja Rosda.

[11] Akay, H., \& Boz, N. (2010). The Effect of Problem Posing Oriented Analyses-II Course on the Attitudes towards Mathematics and Mathematics Self-Efficacy of Elementary Prospective Mathematics Teachers. Australian Journal of Teacher Education, Vol 35 Issue 1, pp. 59-75.

https://doi.org/10.14221/ajte.2010v35n1.6

[12] Mahmudi, A. (2008), "Pembelajaran Problem Posing untuk Meningkatkan Kemampuan Pemecahan Masalah Matematika", presented at Seminar Nasional Matematika FMIPA Universitas Padjajaran, Bandung, Indonesia and Dept. Mathematics, Universitas Indonesia.

[13] Omrod, J.E. (2012). Human Learning (6th ed). Upper Saddle River: Pearson Education.

[14]Brown, Stephen I. dan Marion I., Walter. (2005). The Art of Problem Posing Third Edition. London : Lawrence Erlbaum Associates.

[15] Abu-Elwan, Reda. (2002). Effectiveness of Problem Posing Strategies on Prospective Mathematics Teachers' Problem Solving Performance. Journal Of Science and Mathematics Education in Southeast Asia, Vol 25 Issue 1, pp. 56-69. Available: http://www.recsam.edu.my/R\&D_Journals/YEAR2002/2002Vol25No1/56-69.pdf

[16] Irawati, R. K. (2015). Pengaruh Model Problem Solving dan Problem Posing serta Kemampuan Awal terhadap Hasil Belajar Siswa. Jurnal Pendidikan Sains (JPS), Vol 2 Issue 4, pp. 184-192.

[17] Arikunto, Suharsimi. (2007). Prosedur Penelitian; Suatu Pendekatan Praktik. Jakarta: Rineka Cipta

[18] Anizar, A. \& Purwanti. (Sept. 2016). Peningkatan Komunikasi Matematis dan Kemandirian Belajar Siswa melalui Pendekatan Problem Posing berbantuan Mind Map. Jurnal Didaktik Matematika, Vol 3 Issue 2, pp. 19-34. Available: from www.jurnal.unsyiah.ac.id/DM/article/download/5639/4670

[19] Nurjanah, Erni, "Efektivitas Metode Problem Posing Terhadap Self-Regulated Learning Dan Pemahaman Konsep Matematika Siswa SMK", M.Pd. thesis, Pasundan University, Bandung, Indonesia. Available: repository.unpas.ac.id/1043/1/138060114_Erni\%20Nurjanah_ok.docx

[20] Guvercin, S. \& Verbovskiy, V. 2014. The Effect of Problem Posing Tasks Used in Mathematics Instruction to Mathematics Academic Achievement and Attitudes Towards Mathematics. International Online Journal of Primary Education, Vol 3 Issue 2, pp. 59-65. 